MOOCs and social learning: a healthcare sector case study

\title{
An evaluation of social learning and learner outcomes in a massive open online course (MOOC): A healthcare sector case study
}

\author{
Valerie Anderson ${ }^{1}$, Jonny Gifford ${ }^{2}$, Janet Wildman ${ }^{3}$ \\ 1. Faculty of Business and Law, University of Portsmouth, UK \\ 2. Chartered Institute of Personnel and Development, London, UK \\ 3. Independent Associate UK
}

Corresponding author:

Dr. Valerie Anderson, Reader in Human Resource Development, University of

Portsmouth. T: +44(0)2392844029. E: valerie.anderson@port.ac.uk

\section{Author notes}

1. Author names are listed alphabetically but all named authors contributed equally to a collaborative and collective authorship process for this manuscript.

2. This research was supported by Horizon in NHS Improving Quality (NHS IQ) now part of the Strategy and Innovation Directorate in NHS England. Reports from this project are available from: https://www.cipd.co.uk/hr-resources/research/school-health-care-radicalsimpact.aspx. and Wildman, J. and V. Anderson (2016) "School for Health and Care Radicals: Supporting Change Leaders in Organisations." HR Bulletin. 10(2): 21-23. University of Portsmouth: UK. http://www.port.ac.uk/media/contacts-anddepartments/pbs/os-and-hrm/HR-Bulletin-Vol-10-issue-2-2016.pdf .

3. At the time of the research, Janet Wildman was employed by Horizons NHS Improving Quality Team

4. The authors acknowledge the contribution of M. Stella Martorana to the project reported in this paper. At the time of the HRD intervention and its evaluation discussed in this paper M. Stella Martorana was employed by Chartered Institute of Personnel and Development (CIPD), London, UK. 
MOOCs and social learning: a healthcare sector case study

\section{An evaluation of social learning and learner outcomes in a massive open online course (MOOC): A healthcare sector case study}

This paper responds to calls for new inquiries into the use of technology in HRD. We examine how, and to what extent, social media tools contribute to learner experiences and learner outcomes in an HRD intervention in a workplace context. We analyse qualitative and quantitative data relating to a massive open online course (MOOC) in a healthcare sector case study setting. We examine the interaction between the MOOC programme, social learning through social media tools and learner outcomes. The results of our evaluation show that usage of social media tools does not significantly affect knowledge outcomes but social media usage enhances affective outcomes. We conclude that social media tools can foster productive social learning processes. We also find evidence of some reluctance to engage with the technologies and declining patterns of interactivity using social media over the duration of the MOOC programme. We conclude that a more nuanced theorization to take account of personal and professional workplace context is necessary to explain how learners regulate their engagement with social media tools and the effect of social technologies for sustained social learning in HRD interventions.

Keywords: social learning, technology, workplace learning; healthcare, social media.

\section{Introduction and purpose}

The increasing prevalence of web-enabled technologies and their use as a part of HRD interventions has led to calls for new inquiries into the use of technology in HRD (Li 2013). Empirical research into the effects of technology enhanced learning which focuses on the higher education sector is available (c.f. Hwang 2018; Lin and Hwang 2018; Walker, Voce, and Jenkins 2016; Mooji, Steffens, and Andrade 2014). However, less scholarly attention has been given to the effect of technology in workplace and professional learning and development contexts (Abdullah and Ward, 2016; Balatsoukas et al. 2015; Egloffstein and Ifenthaler 2017; Šumak, Heričko, and Pušnik 
MOOCs and social learning: a healthcare sector case study

2011). In this paper we contribute an evaluation of the ways in which social media as a basis for social learning contributes to learner experiences and learner outcomes in workplace contexts.

Social media as a basis for social learning is associated with informal, applied and generative learning (Egloffstein and Ifenthaler 2017. Although limited by different patterns of technology usage in workplace contexts (Šumak, Heričko, and Pušnik 2011), the use of social media as a mechanism of learning is often portrayed as 'boundaryless' (Ryberg and Christiansen 2008). This paper contributes an examination of learning through social media tools, specifically Facebook and Twitter, as a feature of a massive open online course (MOOC) in a workplace setting. The programme was launched and promoted within the healthcare sector by the UK National Health Service (NHS). This paper is the outcome of 'engaged scholarship' (Van de Ven 2007). The authors represent programme designers and sponsors, a programme evaluator and an academic acting in a 'critical friend' capacity. We analyse and re-interpret data generated through the process of MOOC programme design, implementation and evaluation. The principal question we address is: to what extent, and in what ways, do social media tools, as a feature of a MOOC programme, contribute to learner experiences and learner outcomes? Through this evaluation, we address the dynamic inter-relationship between social media tools as a feature of a corporate MOOC programme and the resulting learner outcomes (Egloffstein and Ifenthaler 2017).

Following this introduction, we outline the conceptual and organizational drivers and epistemological assumptions of the intervention. We explain how this affected the specific MOOC design and intended learner outcomes. We then analyse qualitative and quantitative evaluation data from the MOOC programme, focusing specifically on the relationship between social media tool usage, learner experiences of the MOOC 
MOOCs and social learning: a healthcare sector case study

programme and learner outcomes. We discuss the outcomes of the MOOC in relation to both the intended and unanticipated outcomes. We conclude by considering the theoretical and practical contribution and the implications for further research and HRD practice.

\section{Literature review: HRD, social learning and learning technologies}

In this section we first outline the epistemological grounding from which the MOOC intervention was developed. We then review the literature concerning technology and learning in the workplace that guided our evaluation of learner outcomes from the intervention.

\section{Social learning and communities of practice}

Social learning theory (Bandura 1991, 2001, 2004) represents an important 'driver' of the intervention that we evaluate in this paper. It explains learning as an outcome of interactional features occurring in learner's social (not necessarily technological) environments. Social learning theory emphasises that cognitive and behavioural objectives embedded in learning programme materials are only part of any explanation of learner outcomes. Work-based professional development and personal settings, as well as organizational and systemic contexts and cultures, are important for understanding the learning process and outcomes.

Grounded in social learning theory, the concept of situational learning (Lave and Wenger 1991) proposes that learning cannot be disentangled from the context in which it happens and is often the result of interactions between individuals belonging to the same community or group of professionals. A community of practice or professional learning network (Czerkawski 2016) develops when there is a shared purpose and common area of specialism and members 'act collectively for the benefit of individuals 
MOOCs and social learning: a healthcare sector case study

within the group as well as the group as a whole' (Sims 2018, 53). In organizational settings, communities of practice are theorised to explain individual knowledge sharing; organizational knowledge capital and gain, and competitive advantage (Leonard 2013; Rangachari 2008). Communities of practice can also target specific workplace issues. For example, and with specific relevance to the intervention we discuss in this paper, the literature provides evidence that in the healthcare sector, there has been some shift in their purpose, from supporting a broad drive for learning and knowledge exchange to being focused on improving clinical practice and facilitating evidence-based practice (Fung-Kee-Fung et al. 2008; Ranmuthugala et al. 2011).

\section{Connectivism and social technology in learning}

A further influence on the design of the learning intervention was recognition that interactive learning technologies and other online platforms in the so-called 'networked age' provide opportunities for social learning. Siemens (2005) and Downes (2008) conceptualize connectivist opportunities for information assimilation, knowledge sharing and dialogue that can occur through digitally facilitated interactions.

Connectivism suggests that participation in technologically mediated social interactivity enables cyclical learning processes that lead to continuously modified beliefs, cognition and behaviours (Kop and Hill 2008). In common with social learning theory, connectivism suggests that tacit knowledge can be exchanged through (virtual) observation and reinforcement processes that occur through processes such as storytelling and conversations (Herschel, Nemati, and Steiger 2001; Panahi, Watson, and Patridge 2013).

Critics of connectivism argue that it neglects the effect of social and cultural context on information acquisition and learning processes (Dunaway 2011; Kop and Hill 2008; Thota 2015). Nonetheless, this approach, which formed a further driver of 
MOOCs and social learning: a healthcare sector case study

the programme design, shares a common insight with the social learning theory more generally. In the case of this MOOC programme, the sponsors wished to extend opportunities for learning through interactive social processes making use of social media platforms. The aim was to allow learners 'not only to consume information and knowledge but to be active co-creators of knowledge' (Petreski et al. 2011, 268).

\section{Learner experiences and outcomes of social technology enabled learning}

Social technology tools have become more prominent in recent years in the HRD field (Abdullah and Ward 2016; Balatsoukas et al. 2011) and studies of technology as a feature of workplace learning in health and social care sectors contexts are well represented in the literature base (c.f. Costello et al. 2014; George et al. 2014; Mahmood et al. 2013). However, the literature concerning technology-based learning is inconclusive about learner outcomes. Some studies suggest positive learner outcomes from technology-enhanced learning (TEL) generally, including learner motivation and positive attitudes (c.f. Motschnig-Pitrik and Standl 2013; Hwang and Wu 2014), cognitive learning achievement (Lin and Hwang 2018) and learner self-regulation (Schweighofer and Ebner 2015). With regards to the use of technology-enabled social learning, the literature suggests that social media usage can generate learner experiences of formal, informal and incidental learning (Manca and Ranieri 2016); increased collaboration (Al-Rahmi and Zeki 2017; Ryberg and Christiansen 2008), and reflection (Pimmer 2016). Technology enhanced learning has also been linked to the formation of communities of practice (Petreski et al. 2011; Ranmuthugala et al. 2011; Zhang and Watts 2008) although the extent to which these are sustained has been questioned (Sims 2018). In addition, literature focused specifically on MOOC programmes suggests that many participants may not connect with other learners (Littlejohn et al. 2015; Milligan and Littlejohn 2016; Shen and Kuo 2015) and research reported by Milligan and 
MOOCs and social learning: a healthcare sector case study

Littlejohn (2016) found that MOOC participation did not translate to face-to-face social learning experiences in professional networks.

\section{Influences on use of technology-enabled social learning}

Although the literature is inconclusive about the impact of technology-enabled social learning experiences, it is clear that any potential benefits cannot be realised if people do not use the technologies. Literature relating to learning through technology indicates that learner's perceptions of its usefulness and its ease-of-use are important influences on their attitudes and behaviours (Davis 1989; Hendrix 2008). In addition, complexities of different technological platforms, and uncertainty about the skills required to navigate multiple platforms, have been shown to constitute barriers to acceptance and usage of technology for learning (Petreski et al. 2011, 267).

Workplace and professional 'subjective norms' (Cheng 2011; Van Raaij and Schepers 2008) in individual's professional contexts are further important influences on the uptake of technology for learning purposes and its subsequent outcomes (Walker, Voce and Jenkins 2016; Pillay, Bozalek, and Wood 2015; Pimmer 2016). For example, attitudes towards the group of people who make up an online community is likely to influence participation; online communities are more likely to flourish where respected professionals are participants, and where there is evidence to potential learners of a sense of community within the group or profession updated (Hendrix 2008; Leonard 2013; Milligan and Littlejohn 2016). Perceptions about the levels of activity within the community and how well content is updated are further influences (Leonard 2013). Longitudinal research on virtual communities of practice ( $\mathrm{VCoP})$ undertaken in the healthcare sector further suggests that design factors such as a centralised structure, rotation of VCoP leaders and accessible language (Antonacci et al. Gloor 2017) 
MOOCs and social learning: a healthcare sector case study

encourage participation.

\section{Guiding model}

To summarise, an epistemological grounding in social learning and connectivism influenced the programme design of the MOOC programme we evaluate. Programme designers set out to encourage learner engagement with social media at scale, alongside the MOOC content. The aim was to facilitate the formation of online social learning and virtual communities of practice. The literature indicates a number of challenges in using online platforms and social media activity to facilitate social learning. Figure 1 represents the guiding model for our evaluation of the MOOC programme and its associated social media components intended to facilitate social learning. Our guiding model indicates the importance of the interaction between learner and corporate (NHS) needs, and the aims and intentions of programme designers in the specific organizational context of the MOOC programme design. These interactive factors in turn influence the options for learners to engage with social media tools and other MOOC components. Our guiding model shows the potential for both social learning and individual learning processes. Finally, our epistemological grounding suggests that both learner experiences and learner outcomes are important features for evaluation; these are mutually interactive rather than linear; neither is wholly dependent on the other.

\section{Figure 1 Guiding model}

Guided by this model, and informed by our aim to examine the extent to which social media tools contribute to learner outcomes, we have formulated four research propositions to inform our evaluation of the MOOC programme.

Proposition 1: Participation in the MOOC leads to the achievement of anticipated learner outcomes 
MOOCs and social learning: a healthcare sector case study

Proposition 2: Learner's usage of social media tools enhances the achievement of MOOC learner outcomes

Proposition 3: Learner's usage of social media leads to social learning

Proposition 4: Social learning activity enhances achievement of learner outcomes.

By investigating propositions 1 and 2, we evaluate the impact of the MOOC on intended learner outcomes. By investigating propositions 3 and 4, we explore the social media and social learning processes that occurred through participation in the MOOC programme. In addressing these propositions, our intention is not to engage in theory testing. Rather, we examine evaluation data as a basis from which to better understand and conceptualize the use of social media in HRD interventions as a vehicle for social learning.

In the next section, we outline the programme design, the data collection and methods of analysis. We then present our findings and results before discussing our findings. We conclude by considering the implications of the study for understanding social media as a vehicle for social learning in HRD interventions and the implications for HRD research and practice.

\section{Methodology}

In this section, we first describe the design of the MOOC programme in its case study context. We then outline the methods and analytical procedures we utilized for its evaluation.

\section{MOOC context and aims}

The MOOC in question was an NHS initiative entitled the 'School for Health and Care Radicals' (SHCR) although subsequent versions of the programme have subsequently been renamed to the 'School for Change Agents'. The MOOC's central 
MOOCs and social learning: a healthcare sector case study

aim was to increase the health system's capacity for bottom-up change by developing the skills, confidence and motivation towards change agency of MOOC participants, irrespective of their professional role. The aims of the MOOC were specifically influenced by a substantial body of NHS grey literature concerning large-scale, systemic and rapid organisational change (Bate, Bevan, and Robert 2004; Bevan and Fairman 2014; Bevan, Plsek, and Winstanley 2011; Bibby et al. 2009). This body of work draws on theories of continuous change (Weick and Quinn 1999), innovation in fast-changing environments (Hamel 2012; Kotter 2014), sense making in organisational change (Weick 2000) and social movements (Crossley 2002; Davis and McAdam 2000). This body of literature argues that organisational development has traditionally been held back by an overreliance on programmatic, top-down change interventions (Pettigrew 1998) and that the health service must balance this with bottom-up, emergent change led 'from the edge' (Bevan and Fairman 2014). Therefore, an intention of this MOOC programme was to encourage innovations that were not centrally designed or commissioned. The aim was to foster what was labelled 'new' forms of power and 'social movement' utilising the motivation and agency of employees in contexts outside of the central management or organisational development functions (labelled as 'old power') (Heimans and Timms 2014).

\section{Programme design}

The grounding of the SHCR programme design in principles of social movement, underpinned a MOOC design that integrated the use of social media tools to encourage social learning. This represented a departure for the UK healthcare sector from traditional instructional programme design. In alignment with the principles of social movement, the online learning content was available to all free of charge. On 
MOOCs and social learning: a healthcare sector case study

completion of the MOOC programme participants were able, on a voluntary basis, to make an application for accreditation as a 'Certified Change Agent'.

As indicated already, a further influence on programme design was epistemological assumptions drawn from social learning and connectivist theories (Bandura 1991, 2001). Participation was especially encouraged for teams. To encourage social learning and application of learning in workplace contexts, people were encouraged to join the MOOC with their colleagues. The programme design encouraged knowledge sharing and dialogue through opportunities to use social media tools (Facebook and Twitter) to facilitate interactions between individuals and groups within the wider health-care system.

To summarize, the corporate context for the learning programme was a wider organizational strategy in the case study setting to foster change agency. Programme designers sought to encourage scalable social learning across dispersed health and social care delivery models through its social learning components. Delivery of the core material for the MOOC programme was through webinars delivered 'live', and recorded and made available for subsequent access as necessary. A chat feed was included with the webinar platform, which ran for the duration of each webinar. Twitter and a Facebook group were integrated into the programme design to encourage interactions and social learning outside of the webinars.

\section{Evaluation materials and methods}

The data which we analyse here were gathered in an applied and 'real life' case study setting (Robson and McCartan 2015) over seven months, commencing immediately before the programme was formally initiated and concluding approximately six months after its conclusion. A pre- and post-course survey instrument designed specifically for the project formed the basis for quantitative analysis of learner 
MOOCs and social learning: a healthcare sector case study

outcomes. Initial data collection (T1) took place immediately prior to course commencement. The subsequent (T2) data collection occurred five months later, after completion of the programme. Qualitative semi-structured telephone interviews were also undertaken following the completion of the programme. These examined learner's experiences and usage of the social media tools and the impact of their learner experiences on learner outcomes. We use the data to explore our four propositions as follows:

Propositions 1 and 2: Learner outcomes from MOOC participation (P1) and the enhancing effects of social media usage (P2) are principally measured quantitatively through a purposively designed survey instrument and tested statistically.

Proposition 3: The contribution of social media to social learning is investigated qualitatively through analysis of participants' comments.

Proposition 4: The contribution of social learning to learner outcomes is examined both through analysis of the survey data (whether participants joined the MOOC as a group or individually) and through the analysis of qualitative data.

\section{Research population}

1,232 participants registered for this programme. Participants were predominantly from the UK, although the registration data identifies that participants accessed the programme from a range of countries including USA and Australia. Registration data also shows that not all participants were in paid employment in the healthcare sector. Participants represented a wide range of age groups and levels of seniority. Most participants were engaged in work (full-time and part-time, paid and 
MOOCs and social learning: a healthcare sector case study

unpaid) within the healthcare sector but participants also registered from other public sector professions (for example the Police Force) and from locations outside the UK.

\section{Quantitative data}

All participants were invited to participate in the pre-course survey and a response rate of $51.9 \%$ was achieved (639 valid responses). The sample comprised $71.7 \%$ female and $26.3 \%$ male respondents and the average age was 42.81 years. This sample profile is typical of the healthcare workforce in Western Europe and North America (Imison and Bohmer 2014). The T2 survey population comprised the 639 participants who had completed the T1 survey and a response rate of $17.7 \%(\mathrm{n}=113)$ was achieved.

\section{Qualitative data}

All participants in the programme were invited to volunteer to undertake a telephone interview. There were 25 volunteers. As registration data indicated that participants were drawn from a range of roles and contexts, a purposive sample of fifteen interviewees was drawn from the volunteer group (one subsequently withdrew consent) to include as broad a range of contexts as possible (Trochim 2006). Telephone interviews, which were audio recorded and transcribed, enabled contact with programme participants in dispersed geographic locations and time zones. All interview participants were involved in health care roles but the interview sample included: NHS and non-NHS; patient-facing and support function roles; paid and volunteer workers; and participants based inside and outside UK (see Table 1).

(Table 1) 
MOOCs and social learning: a healthcare sector case study

\section{Data analysis}

In this section, the survey instrument design and validation process, and the analytical strategies for quantitative and qualitative data sets, are explained.

\section{Survey instrument design and validation}

A bespoke before and after survey instrument was designed to examine learner outcomes aligned with the change agency aims and objectives of the programme. First, in-depth interviews with course designers, instructors and administrators, and participants in a previous NHS change agency development programme, were undertaken by the programme evaluators. From this interview data, an initial model of programme outcomes was inductively developed. This formed the basis for the construction of the survey instrument, which included 23 items. All items used a 7-point Likert scale, designed to measure specific aspects of respondents' perceived effectiveness as change agents within their organisational settings. The components reflected aspects of change agency that the course aimed to support. Five composite were developed as follows. First, respondent's sense of purpose and motivation, for example, 'I am naturally motivated to improve how we work'. Second, their theoretical understanding, for example, 'I am knowledgeable about models of organisational change'. Third, ability to connect with others to build support for change initiatives, for example, 'I get people interested in change initiatives'. Fourth, propensity to act 'radically' or proactively as change agents, described in the course as 'rocking the boat', for example, 'I challenge traditional ways of working when I think they can be improved'. Fifth, ability to maintain relationships, described in the course as 'staying in the boat', for example, 'I am careful to frame what I want to say so that it has a positive impact'. 
MOOCs and social learning: a healthcare sector case study

As part of the instrument design and validation process, principal component analysis (PCA) was undertaken using KMO measure and Bartlett's test of sphericity and exploration of between-item correlations to achieve item reduction and factor identification. Components were extracted based on eigenvalues 1 and above, and Varimax rotation with Kaiser Normalisation and Direct oblimin rotation were applied to increase factor loadings on items. Missing cases were excluded on a pairwise basis. The PCA confirmed five components of learner outcomes: motivation for change $(\alpha=.647)$; understanding of change models $(\alpha=.843)$; acting radically as a change agent $(\alpha=$ $.754)$; ability to build support for change ( $\alpha=.851)$; and ability to maintain collaborative relationships $(\alpha=.595)$. One item, 'I lead change informally, by connecting with and influencing people' was removed at this stage to improve $\alpha$ for the factor (acting radically) onto which it loaded; the remaining items were all kept to maximise the $\alpha$ scores. Factor scores were computed as mean scores for the included items.

In addition, to address the issues of interaction between learner outcomes and technology enabled social features of the MOOC, further items were added to the T2 survey questionnaire relating to respondents usage of features of the MOOC delivery platform, for example, 'listening to live broadcasts of the modules', 'online chat during module sessions', 'recordings of online modules' and 'social media contributions'.

\section{Quantitative analysis}

A paired samples T-test comparison of the respondents' baseline and postintervention mean scores for the five factors identified as outcomes from the principal component analysis was undertaken to compare learner perceptions of their learning at the commencement and end of the programme. Comparison of means tests, chi-squared test and correlation analysis were undertaken to examine relationships between personal 
MOOCs and social learning: a healthcare sector case study

context and usage of social learning technologies within the programme. T-tests for equality of means were further undertaken to examine the relationship between learner outcomes and reported use of social learning technologies.

\section{Semi-structured interviews}

The purpose of the semi-structured interviews was to examine programme participants' accounts of their experiences in the programme. In particular, interviews explored the interaction of the social media features of the programme and social learning experiences. The interviews took place immediately following the completion of the MOOC programme. The interview schedule comprised five broad areas. First, questions about the interviewee's experience of the social media tools in the programme. Second, the MOOC structure and design. Third, access by interviewees to the course resources. Fourth, their reactions to webinar content. Fifth, questions about application of learning from the programme in professional workplace contexts. Interviews were typically of between 30 and 45 minutes' duration. Interview transcripts were 'member-checked' by interviewees (Anderson 2017) and analysed using NVivo qualitative data analysis software.

An inductive thematic analysis process following the schema outlined in Braun and Clarke (2006) was undertaken. Initial examination of the transcripts resulted in the identification and refinement of 32 codes. These were then reorganized to reflect important areas identified in the guiding model for the evaluation: learner outcomes; learner experiences and social learning technologies. For learner outcomes, following Bloom's (1956) seminal taxonomy, which remains recognized within the healthcare as well as other educational and e-learning contexts (c.f. George et al. 2014), fifteen themes were identified relating to: knowledge, skills and attitudes. A further twelve 
MOOCs and social learning: a healthcare sector case study

themes were identified describing features of learner experiences, workplace context and personal and professional context. Five themes related to social media experiences.

\section{Data validity and reliability}

Validity data for the scales developed in the survey instrument are included in the explanation of survey design. In relation to potential bias in attrition between $\mathrm{T} 1$ and T2 we compared individual differences between respondents who completed both waves of the survey and those who completed wave one only. We found no significant differences in these two groups at baseline, even at the $\mathrm{p}<0.1$ level, in respondents' age $(\mathrm{t}=1.137 ; \mathrm{df}=621 ; \mathrm{N}=515$ for wave one only and 108 for both waves $)$, gender $\left(\chi^{2}=0.423\right.$; $d f=1 ; N=519$ and 107), whether or not they worked for the UK NHS $\left(\chi^{2}=0.039 ; d f=1\right.$; $\mathrm{N}=529$ and 110) and seniority, measured as respondents' distance from the CEO of their organisations $\left(\chi^{2}=6.053 ; \mathrm{df}=5 ; \mathrm{N}=435\right.$ and 93$)$.

For the qualitative data the issues of methodological integrity; fidelity to the programme and the research aim; perspective management; data adequacy; and 'groundedness' are important indicators of validity (Levitt et al. 2018). The viewpoints expressed by interviewees reflect their experiences 'in context'. The timing of data collection at the conclusion of the programme also meets criteria of 'perspective management'. The purposive selection of interviewees to represent different professional and workplace contexts, including patient facing, management, and non UK-contexts is also relevant to the criteria of data adequacy.

\section{Findings and results}

In this section, we begin by assessing learner outcomes (Proposition 1) before considering usage of social media and its impact on learner outcomes (Proposition 2). We then consider the relationship between social media usage and social learning 
MOOCs and social learning: a healthcare sector case study

(Proposition 3) before examining the effect of social learning processes on learner outcomes (Proposition 4).

\section{Learner outcomes (Proposition 1)}

Principal component analysis identified five components of the specific changeagency related learner outcomes (see Table 2). First, motivation for change, covering attitudes towards making improvements and general strength of purpose in one's work. Second, understanding of change models, covering technical knowledge and knowing when to apply different approaches. Third, acting radically as a change agent, covering challenging received wisdom and assuming legitimacy to act. Fourth, ability to build support for change, covering promoting interventions, inspiring and guiding colleagues, and leadership self-awareness. The final learner outcome was the ability to maintain collaborative relationships, covering propensity to collaborate or conflict with others and attention to one's personal impact.

\section{(Table 2)}

The results of the paired samples T-test comparison of respondents' baseline and post-intervention mean scores for these outcomes (Table 3) provide evidence of significant differences at the point of the $\mathrm{T} 2$ survey in four of the five factors. The standardized mean-difference effect sizes indicate a small impact on motivation for change $(d=0.225 ; \mathrm{p}<0.05)$ : a large impact on understanding of organisational change $(\mathrm{d}=1.032 ; \mathrm{p}<0.001) ;$ a moderate impact on acting radically $(\mathrm{d}=0.473 ; \mathrm{p}<0.001)$; and a moderate-to-large impact on 'connecting with others to build support for change' $(\mathrm{d}=$ 0.695; $\mathrm{p}<0.001)$. Although a small effect size is evident for maintaining relationships, the finding is not significant $(\mathrm{d}=0.139 ; \mathrm{p}>0.1)$.

(Table 3) 
MOOCs and social learning: a healthcare sector case study

Initial analysis of qualitative data, summarized in Table 4, provide additional findings with relevance to learner outcomes. These data suggest that, in addition to the knowledge-related outcomes of the programme, further unanticipated learner outcomes associated with skills of reflection through 'story-telling and framing' and skills of selfawareness were reported. For example 'and the self-awareness. That's important.

That's another one that I'm going to be working with for some time now' (Interview 13). The data also identify additional attitudinal and affective learner outcomes, including: empathy, confidence, perseverance, motivation, 'assume permission to act', and 'energy to deliver on change'.

\section{(Table 4)}

\section{Learner outcomes and engagement with social media (Proposition 2)}

In considering this proposition, we begin with an assessment of the usage of the social media tools and then consider the impact on learner outcomes. Analysis of the Twitter platform usage indicates 20,786,339 impressions of the 'hashtag' \#SHCR across 14,288 tweets over the duration of the programme. The MOOC username attracting 1,686 'followers' and the username (@School4Radicals) reached 35,044 unique Twitter accounts. However, our data also indicate that a substantial proportion of learners did not engage with the social media tools. Analysis of the Facebook usage data indicates that only $35 \%$ of MOOC programme registrants $(n=426)$ joined the Facebook group, of which $76 \%$ were female and $23 \%$ were male (1\% undisclosed); a gender distribution which is consistent with the programme participant sample. Analysis of levels of interactivity in the Facebook group also show 240 original posts across the five-week duration of the programme. Of these, 162 posts generated 918 responses. During this period, 156 programme participants (37\% of the Facebook group) posted new comments or responded to others' comments; a further $25 \%$ 'liked' posts without 
MOOCs and social learning: a healthcare sector case study

commenting but the remaining $38 \%$ of group members were inactive. Analysis also indicates varying levels of participation over the duration of the programme. Higher levels of activity occurred at the commencement and conclusion of the MOOC programme.

Responses to T2 survey suggest that $52 \%$ of respondents took part in the online chat facility associated with the live on-line webinar programmes that comprised the MOOC, and 49\% reported that they connected with others through social media. Analysis of the T2 data found no significant relationship between age, gender and seniority relating to participation in the MOOC online chats; with interaction with other participants via social media, or with face-to-face social learning through participating in the course as a group with colleagues (see appendix).

Qualitative data from the T2 survey further illustrate the reluctance by some MOOC participants to engage with the social media tools. For example:

[I] found the whole [Tweet] chat a waste of my time, left isolated and bemused, lacking any real direction! I see lots of promise and potential here so keep at it, but please work on taking me with you, I just didn't get either the mechanism of Twitter at the technical 'how to' level, nor the value of it to me as a change agent felt like glamour over substance. Where does one go to even understand what a Twitter chat is, how to interact with it and etiquette and the like? Then make doubly clear in plain English where one finds what is to be the subject of the chat. The provided signposting left me cold and abandoned ..I just missed the essence of the value proposition of the chat (anonymous T2 survey respondent).

I don't belong to Facebook. I find it a bit annoying that it plays such a central role in the School. I understand the role of social media, but also like to have some privacy for my personal life. I will join Twitter as I am curious and it allows me to maintain my sense of privacy' (anonymous T2 survey respondent).

Taken as a whole, therefore, these usage data suggest that, at best, half of programme participants made some use of the social media tools in addition to the on- 
MOOCs and social learning: a healthcare sector case study

line webinars that comprised the core of the MOOC programme. However, our results suggest that this made no significant impact on the achievement of intended learner outcomes. Analysis of the differences between T1 and T2 survey data summarized in Table 5 show no significant relationships between engagement with online social technology tools and learner outcomes. Therefore, in response to proposition 2, our evaluation showed no increased impact of social media usage on anticipated learner outcomes.

\section{(Table 5)}

\section{Social learning experiences (Proposition 3)}

In presenting findings related to the use of social media technologies as a feature of social learning we draw on the qualitative data gathered through the semi-structured interviews, the T2 survey process and the Facebook Forum posts.

All but two of the interview participants made explicit reference to the benefits of involvement in a network of peers accessed through their engagement with the social media tools. The analytical outcomes from the interviews, summarised in Table 4, highlight the descriptions of these learner experiences, which included 'support and validation through a network of peers'; 'encourage and support others'; 'foster involvement and support'; and 'align with a shared purpose and mission'. With specific reference to the social media tools, the data indicates that these provided opportunities to extend learning from the webinar content through interaction with others and knowledge sharing. For example:

I thought it was a really interesting aspect to see what other people had to say about what was on screen, but also people sharing links to other interesting articles and documents, but also just sharing their experiences as well of how they find things in their day to day lives and things like that (Interviewee 12) 
MOOCs and social learning: a healthcare sector case study

A further feature of the learning experience reported in the interviews was the opportunity to 'reflect and distil tacit knowledge' as a feature of continuous learning and development. Two quotations illustrate this point:

What was really interesting was that there were threads that went through every model. You never lost that thread really, you'd come across it again in a later model. I took things away from every single one really...it's an amazing resource to have to look back on, to reflect on. So yes I thought it was an amazing experience. (Interview 13).

'I think the conversation over the weekend has helped to embed the ideas, with all these great additional viewpoints layered on and offering a breadth of perspectives.' (SHCR participants, Facebook forum).

Therefore, although our quantitative data indicates no significant impact on intended learner outcomes from engagement with social media tools, our qualitative data indicates that participants who engaged with these tools reported positive social learning experiences. These led to an enhanced sense of support, validation; encouragement, and alignment with a shared purpose relating to the change agency purpose of the MOOC programme. In particular, the findings suggest that interaction with others facilitated through social learning technologies provided learners with a sense of both collective agency and motivation. These two anonymized quotations drawn from the Facebook Group forum illustrate this point:

'Fantastic being part of this global movement. I think this is the key one for me, and learning how to support others to believe the same' and 'I'm happy to learn there is such an amazing community building up the positivity of all the things we CAN do to impact health and care beginning at the personal level. Such a strong believer of this concept and the energy built by the collective belief in improvement WILL manage to get it done!!' 
MOOCs and social learning: a healthcare sector case study

'I'd say the networks and social interaction are invaluable. They provide a safe space for us as a group to reflect on, help one another with, and work through the material that we heard presented on Friday. I would, therefore, say that, for me, the effectiveness of the two learning modes are indissoluble and complementary.'

\section{Social learning and learner outcomes (Proposition 4)}

Finally, we consider survey data to identify the effect of participation in the MOOC as an individual or as part of a group (Tables 5 and 6) and interview data addressing the relationship between social learning and learner outcomes. Our results and findings suggest a range of learner outcomes from the social learning experiences, although these outcomes extend beyond the intended programme outcomes.

Table 5 provides evidence of the effect on learner outcomes of those respondents who reported participating in the MOOC 'alone' or as part of a team. This indicates no significant effect on four of the five intended learner outcomes. However, the analysis indicates a significant relationship between participation as part of a team and the learner outcome concerned with capability to maintain collaborative relationships. This result derives from small respondent numbers (Table 6) so, although the impact size observed from analysis of this relationship is large, this indicative result that may not be generalizable to a larger population.

\section{(Table 6)}

Our analysis of qualitative data provides further insight into the relationship between social learning, learner outcomes and learner experiences. In relation to workplace context, the data provides rich description of participant's feelings of isolation in relation to change agency in their workplace contexts and their perceptions of frustration due to organizational 'inertia'. Many interviewees, from both the UK and elsewhere, perceived their workplace context to be hierarchical, over-regulated and bureaucratic. In describing these contexts interviewees referred to their feelings of 
MOOCs and social learning: a healthcare sector case study

loneliness and powerlessness prior to commencing the MOOC programme. This was a feature of the interviews regardless of the level of seniority of the participant, for example: 'It's very easy to get tied down with the bureaucracy and the false assurance, particularly as a director in a large organisation' (Interview 4); 'but realistically ...your way of working seems to be often swimming against the tide' (Interview 11). However, interviewees also reflected on the important impact of the social learning features of the programme relating with the encouragement and support from others that comprised the network of peers they were able to develop over the duration of the MOOC programme. For example:

The school helped me not [be] worried about people saying 'no' and the resistance to change and kind of accepting that that would be the norm. That actually people will be negative in some ways, but it helps to know that in advance and not take it personally and not just give up with one 'no' (Interview 7).

Whilst the results of our survey analysis indicate no significant relationship between social media usage and anticipated learning outcomes therefore, the interview data suggest the development of enhanced qualities of perseverance and tenacity through social learning processes. These were described as a personal, emotional or attitudinal 'turnaround' from being at a very 'low ebb' (for example, being close to leaving their job) to being re-energized to promote and lead change. Interviewees ascribed this turn-around as an outcome of the social learning features of the programme. Two interviewees with very different levels of formal authority illustrate this point. Interviewee 13 indicated that 'there's been a huge empowerment ... [the school] has given me the permission to actually say, "Yes go ahead and do it" ... That's the overwhelming thing that's come out of this for me'. Interviewee 4 reflected that 
MOOCs and social learning: a healthcare sector case study

'One of the realisation elements was that it's sometimes easy to forget the power that one has inherited in one's role, because you just think, "Oh, I'm just me"” (Interview 4).

Taken as a whole the data indicate that many programme participants made little, if any, use of the social media tools beyond accessing the on-line 'live' or recorded webinars that comprised the core of the MOOC programme. The data also suggest that no significant relationship is evident between knowledge-related learner outcomes and engagement with social media tools or in face-to-face social learning in workplace contexts. However, interviewees who engaged with the social media tools reported social learning processes that enhanced affective learner outcomes related with collective agency and motivation to apply learning from the programme to achieve personal and organizational change. Interviewees indicated the personal importance of these outcomes for their work in contexts that they variously described as isolating, change resistant, hierarchical and over-regulated. They attributed these outcomes to dialogue and engagement with others through the social learning tools featured in the programme. In summary, these findings suggest that participants who engaged with the social media tools reported a range of knowledge, skills and attitudinal outcomes, both intended and unanticipated. The MOOC programme was effective in the achievement of knowledge related outcomes and the data suggest that engagement with the social learning technologies provided further enhancement to proactive and relational outcomes.

\section{Discussion}

Technology enhanced learning embraces a broad range of different learning opportunities. Our evaluation of this purposively designed MOOC programme enables us to consider the interaction between technology, social learning, and learner outcomes. Although the MOOC programme was designed for a specific case study 
MOOCs and social learning: a healthcare sector case study

context (the UK healthcare sector), its open access features make possible some transferability of our conclusions to other similar professional and workplace settings. In this section, guided by our principal research question, we address the extent that social media as a feature of the MOOC programme contributed to learner outcomes and the ways through which this occurred. In our discussion, we first consider our results in relation to social media usage before considering the relationship between social learning through social media tools and learner outcomes. Finally, we discuss the interaction between social learning tools and HRD interventions in workplace and professional contexts more generally.

\section{Social media usage}

Our findings confirm the challenges of technology acceptance as an important factor affecting learning technologies as a feature of HRD interventions ( ̌̌umak, Heričko, and Pušnik 2011). Technology is a well-established feature of healthcare contexts and the promotion of social media tools was a consistent and intentional feature of the programme we consider here. However, our evaluation indicates that only half of the programme participants engaged with the opportunities and only a small proportion of participants regularly and actively engaged with the social learning technologies integrated into the programme. This lends support to concerns that online communities may contain only a small group of contributors who conduct most of the activity, with the majority of other members being ad hoc and passive users (Mahar 2009). Our analysis also confirms the importance of learner's 'subjective norms' (Cheng 2011; Van Raaij and Schepers 2008) and perceived enjoyment (Park, Son, and Kim 2012). These factors may explain the reluctance of a substantial proportion of learners to engage with social learning tools.

\section{Learner outcomes}


MOOCs and social learning: a healthcare sector case study

Consistent with other studies (c.f. Bedford 2019; Lin and Hwang 2018; Milligan, Littlejohn, and Margaryan 2014) our analysis indicates a positive relationship between participation in the MOOC programme and achievement of knowledge-based intended learner outcomes. It also shows some relationship between MOOC programme participation and skills and behaviour outcomes such as 'acting radically' and 'building support for change'. However, it suggests no significant relationship with the intended outcome of 'maintaining relationships'.

Concerning learner outcomes related to relational skills and attitudes, the existing literature base is inconclusive. Some sources suggest that social learning technologies have the potential to enhance collaborative and relational outcomes (c.f. Al-Rahmi and Zeki 2017; Ryberg and Christiansen, 2008). However, doubts are also expressed about the role of MOOCs and social learning technologies in the achievement of skills and attitudes underpinning the application of learning in workplace contexts (Milligan, Littlejohn, and Margaryan 2014; Watson et al. 2016).

Our analysis contributes to this debate. Conceptualization of the affective learning domain describes a series of emotional or attitudinal levels (Krathwohl, Bloom, and Masia 1964). These include learner's awareness of, or willingness to receive specific learning stimuli, as well as response to these stimuli, and acceptance of the values associated with them before internalization and commitment to acting on them. Notwithstanding the empirical and conceptual problems associated with this typology (Pascarella 1985; Wu et al. 2019), our analysis suggests positive acceptance, internalization and motivation to apply learning from the programme to affect personal and organizational change by those who engaged with its social media tools. Although survey responses showed only limited effect on constructs labelled as 'acting radically' and 'maintaining relationships', our qualitative analysis indicates more positive 
MOOCs and social learning: a healthcare sector case study

outcomes for those who participated in social media technologies. These data show that interaction with peers, giving and receiving of support, and encouragement from others, enabled learners to re-evaluate their commitment and value-stance in relation to their personal change agency. Our analysis suggests that storytelling and exchange of ideas and experiences, through the affordances of social media tools, provided the basis for attitudinal 'turnaround', even in workplace contexts described as difficult and frustrating.

\section{Social Learning Experiences}

Our analysis also contributes to debates about the social learning experiences associated with MOOCs. In conventional HRD programmes, social modelling by tutors and 'influential others' is understood to form the basis for important social learning experiences (Natt och Dag 2017). However, technological platforms provide new and increased opportunities for social learning experiences through self-regulated learner interactions with others (both learners and experts) around particular interests and areas of knowledge and expertise (Trust, Carpenter, and Krutka 2017; Milligan, Littlejohn, and Margaryan 2014). Studies in the professional learning literature suggest that participants in MOOCs prioritise content over social learning opportunities, something that our analysis supports. However, our analysis also shows that social learning tools can encourage narrative processes and knowledge sharing as meaningful features of social learning. Information assimilation, dialogue and reflective learning were important features of the learning experience arising from engagement with the social media tools featured in the MOOC programme. These social learning experiences enabled individuals operating in different organizational, personal and professional contexts to benefit from learning networks and to link ideas and 'know-how' from a range of different sources (Milligan, Littlejohn, and Margaryan 2014). Our analysis 
MOOCs and social learning: a healthcare sector case study

suggests that collaborative and relational skill outcomes are more strongly associated with participants who are committed to engagement in social learning processes. We argue, therefore, that when social learning technologies feature in HRD intervention design, it is group or professional identity, in addition to engagement with the technologies per se that may explain enhanced collaborative and relational outcomes.

A further feature of the social learning experience identified by our evaluation relates to learning outside the remit and control of programme designers. In common with other MOOCs, the open access nature of the programme made its content and associated social media tools accessible by a diverse learning population. Studies focused on other MOOC programmes (c.f. Egloffstein and Ifenthaler 2017; Milligan and Littlejohn 2017) have suggested that the size and open access characteristics of MOOCs may dilute relational features of learner experience. However, our evaluation contributes a different perspective. Our analysis shows that the diverse characteristics of the learner population was reported to be a positive feature of participant's social learning experiences as it enabled knowledge sharing that reflected a wider range of organizational, personal and professional contexts. We conclude that programme design with sufficient linkage to applied or professional practice issues makes participant diversity a benefit, rather than a constraint, and encourages the achievement of learner outcomes beyond the domains of knowledge and skill acquisition. Our analysis supports arguments that social learning technologies can generate important professional knowledge, practice sharing and social learning experiences.

\section{Technology and social learning in workplace contexts}

Our analysis adds to the literature about the effect of MOOC programmes and social learning tools in workplace and professional contexts. The programme design we evaluate here sought to exploit the affordances of social media tools to transcend typical 
MOOCs and social learning: a healthcare sector case study

temporal and spatial boundaries and enable interactions between learners as the basis for affective, social and cognitive learning to encourage change agency.

Milligan, Littlejohn, and Margaryan (2014) highlight the importance an integrative pedagogy in MOOC based programmes to encourage learners to integrate knowledge with professional and workplace contexts as a basis for 'metacognition' outcomes. They further indicate that personal and environmental factors in which interventions occur are important for learner outcomes. Our analysis of the different outcomes between participants joining the programme 'alone' or as part of a group supports this assertion, but further indicates the challenges of encouraging learners to engage in such forms of social learning. We conclude that in social, cultural and workplace contexts that are challenging and isolating, social learning technologies provide a means for reflection, self-regulation and collaboration (Trust, Carpenter, and Krutka 2017). Consistent with studies of learning in organizational settings (c.f. Watkins and Kim 2018), our evaluation indicates the important influence of colleagues, mentors, managers or professional contacts within learner's personal and professional contexts. Professional and personal context constitutes the 'space' (Trust, Carpenter, and Krutka 2017) from which both intended and unanticipated learner outcomes occur. Assessment of the micro-context in which social learning through technology occurs is an important feature of any explanation of the interaction between social learning technologies and learner outcomes. Consistent with social learning theory, our analysis indicates that learner's contextually situated 'points of reference' provide the basis for knowledge sharing and encouragement of, and from, others.

The agency and intentions of programme designers in MOOC, as in other forms of programmatic learning interventions, goes some way to explaining the achievement of knowledge-related learner outcomes. Our analysis shows that these are unaffected by 
MOOCs and social learning: a healthcare sector case study

engagement with social media tools. However, social learning technologies provide the opportunity for unanticipated learner outcomes, particularly in relation to the affective domain. Theorization of these outcomes requires greater attention to micro-contextual factors that influence learner avoidance, participation, engagement and perseverance with social learning technologies.

\section{Conclusion}

Social technologies such as Twitter and Facebook increasingly feature in informal and formal learning practices and professional development processes. MOOC programmes are a growing feature of academic provision. However, more research into their use in applied workplace and professional contexts is required to understand and explain the role of technology in as a feature of HRD policy and practice. Our examination of the outcomes of a MOOC programme that integrated opportunities for social learning through social media tools contributes to this emerging research and practice agenda

Our evaluation makes four important contributions. First, it confirms the importance of professional and workplace context on acceptance and use of social learning technologies within HRD interventions and for participation in TEL more generally. Second, our examination of the learner outcomes resulting from the MOOC programme and social media tools shows that the achievement of knowledge related learner outcomes is unaffected by participation in social learning through these social media technologies. Third, our evaluation indicates that social media can contribute to important affective, attitudinal and values-based outcomes. Fourth, comparing MOOC learners who participated as a group to those who took part individually, we provide evidence that MOOC-enabled social learning can have additional learner benefits. In spite of workplace contexts consistently described by participants as highly regulated, 
MOOCs and social learning: a healthcare sector case study

personally isolating and bureaucratic, we conclude that social learning achieved through social media tools provided the basis in this MOOC programme for enhanced attitudinal or 'affective' learner outcomes that would not otherwise have been achieved.

\section{Limitations and implications}

Our evaluation is practice-driven and concerns a specific MOOC programme that involved technology enabled social learning with a contextualized scope and purpose. We recognize the limitation of our focus on a single HRD intervention and the self-selecting nature of the research participants. We further recognize that the inclusion of participants from different organizations and country locations resulting from the open access features of this MOOC programme may be regarded as a research design limitation. However, the diversity of programme participants was contextually beneficial and the intention of this evaluation was not to employ a theory testing design. Rather our purpose was to evaluate the programme as a basis from which to better understand and explain technology enabled social learning as a feature of an organizational HRD intervention. The inclusion of participants from other related sectors also supports our assertion of transferability of our conclusions to other public sector or non-profit organizational and professional settings.

Our evaluation enables us to identify a number of implications for MOOC design and for understanding the use of social learning technologies as a feature of HRD policy and practice. First, social, professional, cultural and workplace context are important factors affecting the effectiveness of TEL as feature of organizational HRD. Specifically, successful deployment of social learning technologies as a feature of HRD interventions requires careful consideration of professional and workplace-learning context. Support and encouragement to overcome patterns of technology avoidance are necessary. Second, attention by programme designers is needed to the personal and 
MOOCs and social learning: a healthcare sector case study

professional 'triggers' that can be deployed to encourage and support productive and sustained engagement by learners with ongoing social learning through social media tools. Third, programme design guidelines are necessary to specify intended learner outcomes. However, evaluation guidelines should recognize unanticipated learner outcomes that may occur from engagement with social learning technologies. Further research into the effect of social learning through technology-based tools on learning outcomes in the affective domain is required. Fourth, in organizational and professional contexts where patterns of task intensity and work design inhibit social interaction (c.f. Bedford 2019) then social learning technologies, as a feature of applied workplace and professional development programmes, may be beneficial for collaborative, professional and relational learning.

Digital technology provides the HRD field with opportunities for new and distinctive models of networked learning and professional development. This paper contributes to the developing stream of research into the use of technology in HRD. MOOCs provide a flexible way for learners in dispersed organizational and professional settings to access learning opportunities. Social learning technologies have the potential to overcome temporal and spatial barriers and provide new learning opportunities. Our evaluation shows the important effects of organizational, professional and workplace context in the ways that learners regulate their engagement with technologically enabled social learning opportunities. It further explains how, even in contexts that may be overregulated and isolating, social learning achieved through social media tools can provide the basis for important attitudinal or 'affective' learner outcomes.

\section{References}

Abdullah, F., and R. Ward. 2016. "Developing a General Extended Technology Acceptance Model for E-Learning (GETAMEL) by analysing commonly used 
MOOCs and social learning: a healthcare sector case study

external factors." Computers in Human Behavior 56: 238-256.

doi.org/10.1016/j.chb.2015.11.036.

Al-Rahmi, W.M., and A.M. Zeki. 2017. "A model of using social media for collaborative learning to enhance learners' performance on learning." Journal of King Saud University - Computer And Information Sciences 29 (4): 526535. DOI 10.1016/j.jksuci.2016.09.002

Anderson, V. 2017. “Criteria for Evaluating Qualitative Research.” Human Resource Development Quarterly 28 (2): 125-133. doi:10.1002/hrdq.21282.

Antonacci, G., A. F. Colladon, A. Stefanini, and P. Gloor. 2017. "It is rotating leaders who build the swarm: social network determinants of growth for healthcare virtual communities of practice.".Journal of Knowledge Management 21 (5): 1218-1239. doi.org/10.1108/JKM-11-2016-0504

Balatsoukas, P., C. M. Kennedy, I. Buchan, J. Powell, and J. Ainsworth. 2015. "The Role of Social Network Technologies in Online Health Promotion: A Narrative Review of Theoretical and Empirical Factors Influencing Intervention Effectiveness.” Journal of Medical Internet Research 17 (6): 141. doi:10.2196/jmir.3662

Bandura, A. 1991. "Social cognitive theory of self-regulation." Organizational Behaviour and Human Decision Processes 50(2):248-287.

Bandura, A. 2001. "Social cognitive theory: An agentic perspective." Annual Review of Psychology 52:1-26.

Bandura, A. 2004. "Social cognitive theory for personal and social change by enabling media." In Entertainment-education and social change: History, research, and practice edited by M. J. Singhal, E. Cody, M. Rogers, and M. Sabido.75-96. Mahwah, NJ: Lawrence Erlbaum.

Bate, P., H. Bevan, and G. Robert. 2004. "Towards a million change agents: a review of the social movements literature: implications for large scale change in the NHS.” NHS Modernisation Agency. https://discovery.ucl.ac.uk/id/eprint/1133/1/million.pdf

Bevan, H. and S. Fairman. 2014. "The new era of thinking and practice in change and transformation: a call to action for leaders of health and care." Coventry: NHS Improving Quality. https://www.england.nhs.uk/improvement-hub/wpcontent/uploads/sites/44/2018/09/Change-and-Transformation-White-Paper.pdf 
MOOCs and social learning: a healthcare sector case study

Bevan, H., P. Plsek, and L. Winstanley. 2011. "Leading large scale change: a practical guide.” Coventry: NHS Institute for Innovation and Improvement. https://www.england.nhs.uk/improvement-hub/wpcontent/uploads/sites/44/2011/06/Leading-Large-Scale-Change-Part-1.pdf [Accessed 01/11/2019].

Bibby, J., H. Bevan, E. Carter, P. Bate, and G. Robert. 2009. "The power of one, the power of many: bringing social movement thinking to health and healthcare improvement." Coventry: NHS Institute for Innovation and Improvement. https://www.slideshare.net/NHSIQlegacy/the-power-of-one-the-power-of-many$\underline{33550524}$

Bloom, B.S.1956. Taxonomy of Educational Objectives. Boston, MA: Allyn and Bacon.

Braun, V. and V. Clarke. 2006. "Using thematic analysis in psychology." Qualitative Research in Psychology 3 (2): 77-101. doi.10.1191/1478088706qp063oa

Christensen, G., A. Steinmetz, B. Alcorn, A. Bennett, D. Woods, and E. Emanuel. 2013. "The MOOC Phenomenon: Who Takes Massive Open Online Courses and Why?" VOCED plus. http://hdl.voced.edu.au/10707/279356.

Clarà, M. and E. Barberà. 2013. "Learning online: massive open online courses (MOOCs), connectivism, and cultural psychology." Distance Education 34(1):129-136. doi.org/10.1080/01587919.2013.770428.

Costello, E., M.Corcoran, J.S. Barnett, M. Birkmeier, R. Cohn, O. Ekmekci, and B. Walker. 2014. "Information and communication technology to facilitate learning for students in the health professions: Current uses, gaps and future directions." Online Learning: Official Journal of the Online Learning Consortium 18(4). http://olj.onlinelearningconsortium.org/index.php/jaln/ article/view/512/118

Crossley, N. 2002. Making sense of social movements. Buckingham: Open University Press.

Czerkawski, B. 2016. "Blending Formal and Informal Learning Networks for Online Learning." The International Review of Research in Open and Distributed Learning 17 (3). doi:10.19173/irrodl.v17i3.2344

Davis, F. D. 1989. "Perceived usefulness, perceived ease of use, and user acceptance of information technology." MIS Quarterly 13 (3), 319-340.

Davis, G.F. and D. McAdam. 2000. "Corporations, classes and social movements after managerialism." Research in Organisational Behaviour 22: 193-236. 
Derry, J. 2008. "Technology-Enhanced Learning: A Question of Knowledge." Journal of Philosophy of Education 42 (3/4): 505-519. doi.10.1111/j.14679752.2008.00638.x.

Downes, S. 2008. "Places to Go: Connectivism \& Connective Knowledge." Innovate: Journal of Online Education 5

(1):6. http://nsuworks.nova.edu/innovate/vol5/iss1/6

Dunaway, K. M. 2011. "Connectivism: Learning Theory and Pedagogical Practice for Networked Information Landscapes." Reference Services Review 39 (4): 675685. doi.org/10.1108/00907321111186686.

Egloffstein, M. and D. Ifenthaler. 2017. "Employee Perspectives on MOOCs for Workplace Learning." TechTrends 61:65-70. doi.10.1007/s11528-016-0127-3.

Fung-Kee-Fung, M. M. F., E.M. Goubanova, K.B, Sequeira, A.B. Abdulla, R.M.Cook, C.C. Crossley, H.M. Stern, et al. 2008. "Development of Communities of Practice to Facilitate Quality Improvement Initiatives in Surgical Oncology." Quality Management in Health Care 17(2), 174. doi.10.1097/01.QMH.0000316995.79167.be

George, P. P., N. Papachristou, J.M. Belisario, W. Wang, P.A. Wark, Z. Cotic, J. Car. 2014. "Online eLearning for Undergraduates in Health Professions: A Systematic Review of the Impact on Knowledge, Skills, Attitudes and Satisfaction.” Journal of Global Health 4 (1):1-17. doi.org/10.7189/jogh.04.010406

Hamel, G. 2012. What Matters Now: How to Win in a World of Relentless Change, Ferocious Competition, and Unstoppable Innovation. San Francisco: JosseyBass.

Hendrix, D. M. 2008. "Factors influencing participation in global online communities of practice.” (3322888 D.M.), University of Phoenix, Ann Arbor. https://search.proquest.com/docview/304309961 ?accountid=136762

Heimans, J. and H. Timms. 2014. "Understanding 'new power'." Harvard Business Review December. https://hbr.org/2014/12/understanding-new-power

Herschel, R., H. Nemati, and D. Steiger. 2001. "Tacit to explicit knowledge conversion: knowledge exchange protocols." Journal of Knowledge Management 5 (1): 107116. doi.org/10.1108/13673270110384455 
MOOCs and social learning: a healthcare sector case study

Hwang, A. 2018. "Online and Hybrid Learning." Journal of Management Education 42(4): 557-563. doi.org/10.1177/1052562918777550.

Hwang, G.-J., and P.-H. Wu. 2014. "Applications, impacts and trends of mobile technology-enhanced learning: A review of 2008-2012 publications in selected SSCI journals." International Journal of Mobile Learning and Organisation 8 (2): 83-95. doi.10.1504/IJMLO.2014.062346.

Imison, C. and R. Bohmer. 2013. "NHS and Social Care Workforce: Meeting our Needs Now and in the Future?" Perspectives: The Kings Fund. https://www.kingsfund.org.uk/sites/default/files/field/field_publication_file/pers pectives-nhs-social-care-workforce-jul13.pdf

Igbaria, M., and S. Parasuraman. 1989. "A path analytic study of individual characteristics, computer anxiety and attitudes toward microcomputers." Journal of Management 15 (3): 373-388. doi.org/10.1177/014920638901500302.

Imison, C. and R. Bohmer. 2014. "NHS and social care workforce: meeting our needs now and in the future?" Perspectives. London: The Kings Fund. https://www.kingsfund.org.uk/sites/default/files/field/field_publication_file/pers pectives-nhs-social-care-workforce-jul13.pdf

Kaminskienè, L., A. Rutkienè, and E. Trepulè. 2015. "Integration of technology enhanced learning within business organizations: Which strategy to choose?" Turkish Online Journal of Educational Technology 14 (4): 7892. http://www.tojet.net/articles/v14i4/1448.pdf

Kop, R., and A. Hill. 2008. "Connectivism: Learning theory of the future or vestige of the past?" The International Review of Research in Open and Distance Learning 9 (3). http://www.irrodl.org/index.php/irrodl

Kotter, J.P. 2014. Accelerate. Brighton, MA: Harvard Business Review Press Krathwohl, D.R., B.S. Bloom and B.B. Masia. 1964. Taxonomy of Educational Objectives, Book II. Affective domain. New York, NY: David McKay Company, Inc.

Lave, J., and E. Wenger. 1991. Situated learning. Legitimate peripheral participation. Cambridge: University of Cambridge Press. 
MOOCs and social learning: a healthcare sector case study

Leonard, K. G. 2013. "Online communities of practice: Factors that affect usage from a multiple stakeholder perspective.” (3591385 Ph.D.), Capella University, Ann Arbor. https://search.proquest.com/docview/1433912503?accountid=136762

Li, J. 2013. "Web-based technology and the changing landscape of HRD." Human Resource Development International 16 (3):247-250. doi.10.1080/13678868.2013.799401

Lin, H-C. and G-J. Hwang. 2018. "Research trends of flipped classroom studies for medical courses: a review of journal publications from 2008 to 2017 based on the technology-enhanced learning model." Interactive Learning Environments. doi.10.1080/10494820.2018.1467462.

Littlejohn, A., N. Hood, C. Milligan, and P. Mustain. 2015. "Learning in MOOCs: Motivations and self-regulated learning in MOOCs." The Internet and Higher Education 29: 40-48. DOI:org/10.1016/j.iheduc.2015.12.003

Mahar, G. J. 2009. "Factors affecting participation in online communities of practice." (NR56138 Ph.D.), University of Waterloo (Canada), Ann Arbor. https://search.proquest.com/docview/305141269?accountid=136762

Mahmood, H., B. Hatem, L. Xialolin, and M. Featherman. 2013. "From e-learning to social learning: A health care study." European Journal of Training and Development 37(9): 851-863. doi.org/10.1108/EJTD-10-2012-0062.

Marsick, V. J., and K.E. Watkins. 2001. "Informal and incidental learning." New directions for adult and continuing education 89: 25-34. doi:10.1002/ace.5

Manca, S. and M. Ranieri. 2013. "Is it a tool suitable for learning? A critical review of the literature on Facebook as a technology-enhanced learning environment." Journal of Computer Assisted Learning 29:487-504. doi: 10.1111/jcal.12007.

Manca, S. and M. Ranieri. 2016. "Is Facebook still a suitable technology-enhanced learning environment? An updated critical review of the literature from 2012 to 2015.” Journal of Computer Assisted Learning 32:503-528. doi.10.1111/jcal.12154.

Mavengere, N. and K. Tikkamaki. 2013. "Organizational Learning, Agility and Social Technologies for Enhanced Organizational, Performance." Paper presented at X World Conference on Computers in Education, Torun, Poland. July 2-5. 
MOOCs and social learning: a healthcare sector case study

Milligan, C., and A. Littlejohn, A. 2016. "How Health Professionals Regulate their Learning in Massive Open Online Courses." The Internet and Higher Education 31: 113-121. doi.org/10.1016/j.iheduc.2016.07.005

Milligan, C., A. Littlejohn, and A. Margaryan. 2014. "Workplace Learning in Informal Networks.” Journal of Interactive Media in Education, doi:10.5334/2014-06. JIME http://jime.open.ac.uk/2014/06

Mooji, T., K. Steffens, and M.S. Andrade. 2014. "Self-regulated and Technologyenhanced Learning: a European perspective." European Educational Research Journal 13 (5): 519-528. doi.10.2304/eerj.2014.13.5.519

Motschnig-Pitrik, R., and B. Standl. 2013. "Person-centered technology enhanced learning: Dimensions of added value." Computers in Human Behavior 29:401409. doi.org/10.1016/j.chb.2012.04.013.

Natt och Dag, K. 2017. “A Scholar-Practitioner Perspective on a Leadership Development Program in Health Care: Integrating Connectivism Theory." Advances in Developing Human Resources 19(3): 295 - 313. doi.10.1177/1523422317712671

Panahi, S., J. Watson, and H. Patridge. 2013. "Towards tacit knowledge sharing over social web tools.” Journal of Knowledge Management 17 (3): 379-397. doi.org/10.1108/JKM-11-2012-0364.

Park, Y., H. Son, and C. Kim. 2012. "Investigating the determinants of construction professionals' acceptance of web-based training: an extension of the technology acceptance model." Automation in Construction 22: 377-386. doi.org/10.1016/j.autcon.2011.09.016

Pascarella, E. T. 1985. "Students' Affective Development within the College Environment." Journal of Higher Education 56, 640-663. doi: 10.2307/1981072

Petreski, H., S. Tsekeridou, E, Giannaka, N.R. Prasad, R, Prasad, and Z-H Tan. 2011. “Technology-enabled social learning: a review." International Journal of Knowledge and Learning 7 (3-4), 253. doi.org/10.1504/IJKL.2011.044558.

Pettigrew, A.M. (1998) "Success and failure in corporate transformation initiatives". In. Information technology and organisational transformation Edited by R. D. Galliers, W.R.J. Baets, 271-89. Chichester: Wiley. 
MOOCs and social learning: a healthcare sector case study

Pillay, R., V. Bozalek, and D. Wood. 2015. "The use of technology-enhanced learning (TEL) to facilitate authentic learning: experiences of South African social work educators." Social Work/Maatskaplike Werk 50 (4): 515-532. doi.org/51-3-464

Pimmer, C. 2016. "Mobile learning as boundary crossing: an alternative route to technology-enhanced learning?” Interactive Learning Environments 24 (5):979990. doi:10.1080/10494820.2015.1128211

Rangachari, P. 2008. "Knowledge sharing networks related to hospital quality measurement and reporting." Health Care Management Revie, 33 (3): 253. doi: 10.1097/01.HMR.0000324910.26896.91

Ranmuthugala, G., J.J. Plumb, F.C. Cunningham, A. Georgiou, J.I. Westbrook, and J. Braithwaite. 2011. "How and Why are Communities of Practice Established in the Healthcare Sector? A Systematic Review of the Literature.” British Medical Council Health Services Research 11, 273. doi.org/10.1186/1472-6963-11-273

Robson, C. and K. McCartan. 2015. Real World Research. Chichester: Wiley Rodrigues, O. 2012. "MOOCs and the AI-Stanford like Courses: Two Successful and Distinct Course Format for Massive Open Online Courses.” European Journal of Open, Distance and ELearning. http://www.eurodl.org/?p=archives \&year=2012\&halfyear=2\&article $=516$

Ryberg, T. and E. Christiansen. 2008. "Community and social network sites as Technology Enhanced Learning Environments.” Technology, Pedagogy and Education 17(3): 207-219. doi.10.1080/14759390802383801

Schweighofer, P. and M. Ebner. 2015. "Aspects to be considered when implementing technology-enhanced learning approaches: A literature review." Future Internet 7(1): 26-49. http://www.mdpi.com/1999-5903/7/1/26/htm

Shen, C-W. and C-J. Kuo. 2015. "Learning in massive open online courses: Evidence from social media mining." Computers in Human Behavior 51(Part B): 568577. Doi.10.1016/j.chb.2015.02.066.

Siemens, G. 2005. "Connectivism: A learning theory for the digital age.” International Journal of Instructional Technology and Distance Learning 2(1): 3-10. http://itdl.org/Journal/Jan_05/article01.htm

Sims, J. M. 2018. “Communities of Practice: Telemedicine and Online Medical Communities." Technological Forecasting and Social Change 126:53-63. doi.org/10.1016/j.techfore.2016.08.030 
MOOCs and social learning: a healthcare sector case study

Šumak, B., Heričko, M, and M. Pušnik. 2011. “A Meta-analysis of E-learning Technology Acceptance: The Role of User Types and E-learning technology Types." Computers in Human Behavior. 27 (6): 2067-2077 doi.10.1016/j.chb.2011.08.005

Thota, N. 2015. "Connectivism and the Use of Technology/Media in Collaborative Teaching and Learning." New Directions for Teaching and Learning 142: 81-96. doi:10.1002/tl.20131

Trochim, W. 2006. "Nonprobability sampling". Research Methods Knowledge Base. http://www.socialresearchmethods.net/kb/sampnon.php

Trust, T., J.P. Carpenter, and D.G. Krutka. 2017. "Moving Beyond Silos: Professional Learning Networks in Higher Education." The Internet and Higher Education 35: 1-11. doi.org/10.1016/j.iheduc.2017.06.001.

Van de Ven, A. H. 2007. Engaged Scholarship: A Guide for Organizational and Social Research. Oxford: Oxford University Press.

Van Raaij, E. M., and J.J.L. Schepers. 2008. "The Acceptance and Use of a Virtual Learning Environment in China." Computers \& Education 50 (3): 838-852. doi.org/10.1016/j.compedu.2006.09.001.

Vygotsky, L.S. 1978. Mind and Society: Cambridge, MA: Harvard University Press. Walker, R., J. Voce, and M. Jenkins. 2016. "Charting the development of technologyenhanced learning developments across the UK higher education sector: a longitudinal perspective (2001-2012)." Interactive Learning Environments 24(3): 438-455. DOI: 10.1080/10494820.2013.867888

Watkins K.E., and K. Kim. 2018. "Current status and promising directions for research on the learning organization." Human Resource Development Quarterly 29:1529. doi.org/10.1002/hrdq.21293

Watson, S. L., Loizzo, J., Watson, W. R., Mueller, C., Lim, J., and P.A. Ertmer. 2016. "Instructional design, facilitation, and perceived learning outcomes: an exploratory case study of a human trafficking MOOC for attitudinal change." Educational Technology Research and Development 64(6): 1273-1300. https://doi.org/10.1007/s11423-016-9457-2 
MOOCs and social learning: a healthcare sector case study

Weick, K.E. 2000. "Quality improvement. A sensemaking perspective." In The quality movement and organisation theory, edited by R.E. Cole and W.R. Scott. London: Sage.

Weick, K.E. and R.E. Quinn. 1999. "Organisational change and development." Annual. Review of Psychology 50:361-86.

Wu W-Hsiung, K. Hao-Yun, W Sheng-Hsiu, and C-W. Wang. 2019. "Development and Evaluation of Affective Domain Using Student's Feedback in Entrepreneurial Massive Open Online Courses." Frontiers in Psychology 10: 1109. doi.10.3389/fpsyg.2019.01109.

Zhang, W. and S. Watts. 2008. "Online communities as communities of practice: a case study." Journal of Knowledge Management 12 (4): 55-

71.doi.org/10.1108/13673270810884255 
Figure 1: Guiding model

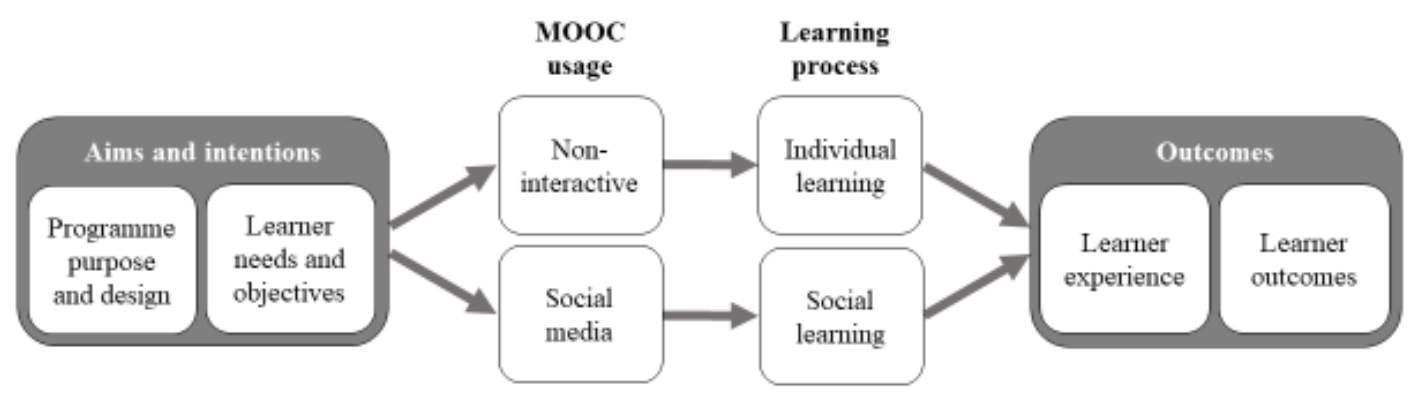

Table 1: Semi-structured interview sample

\begin{tabular}{|l|l|l|l|l|}
\hline & Role & $\begin{array}{l}\text { Gender } \\
\text { F/M }\end{array}$ & $\begin{array}{l}\text { UK/ } \\
\text { Non UK }\end{array}$ & $\begin{array}{l}\text { NHS / } \\
\text { Non-NHS }\end{array}$ \\
\hline 1 & Healthcare Assistant & F & UK & NHS \\
\hline 2 & Deputy Sister & F & UK & NHS \\
\hline 3 & $\begin{array}{l}\text { Quality Improvement } \\
\text { Fellow }\end{array}$ & F & UK & NHS \\
\hline 4 & Communications Director & M & UK & NHS \\
\hline 5 & Head of Quality & F & UK & Non-NHS \\
\hline 6 & $\begin{array}{l}\text { Quality Improvement } \\
\text { Advisor }\end{array}$ & F & Non UK & Non-NHS \\
\hline 7 & Nurse Specialist & F & UK & NHS \\
\hline 8 & Patient Online Volunteer & M & UK & Non-NHS \\
\hline 9 & Patient Safety Co-ordinator & F & UK & NHS \\
\hline 10 & Economic Advisor & F & Non UK & Non-NHS \\
\hline 11 & Head of Practice Support & F & UK & NHS \\
\hline 12 & Service Delivery Manager & M & UK & NHS \\
\hline 13 & Clinical Audit Facilitator & F & UK & NHS \\
\hline 14 & Volunteer Public Governor & M & UK & Non-NHS \\
\hline
\end{tabular}


Table 2: Principal Component Analysis and tests for reliability

\begin{tabular}{|c|c|c|c|c|c|}
\hline Factor & Items & PCA & $\alpha$ & $\mathrm{ICC}^{1}$ & $\mathrm{~N} \mathrm{excl.}^{2}$ \\
\hline \multirow{4}{*}{$\begin{array}{l}\text { 1: Motivation for } \\
\text { change }\end{array}$} & I am naturally motivated to improve how we work. & 0.780 & \multirow[t]{4}{*}{0.647} & \multirow[t]{4}{*}{0.314} & \multirow[t]{4}{*}{3} \\
\hline & I feel a sense of purpose in my day-to-day work. & 0.653 & & & \\
\hline & I reflect on my work experience to help improve practice. & 0.550 & & & \\
\hline & I make suggestions on new ways of thinking or working. & 0.504 & & & \\
\hline \multirow{2}{*}{$\begin{array}{l}\text { 2: Understanding of } \\
\text { change models }\end{array}$} & I know when to use planned or emergent approaches to change. & 0.866 & \multirow[t]{2}{*}{0.843} & \multirow[t]{2}{*}{0.728} & \multirow[t]{2}{*}{20} \\
\hline & I am knowledgeable about models of organisational change. & 0.834 & & & \\
\hline \multirow[t]{3}{*}{ 3: Acting radically } & $\begin{array}{l}\text { If I can see how to make a positive change, I will do it without waiting for } \\
\text { permission. }\end{array}$ & 0.823 & \multirow[t]{3}{*}{0.754} & \multirow[t]{3}{*}{0.405} & \multirow[t]{3}{*}{11} \\
\hline & I encourage others to lead change without waiting for permission. & 0.798 & & & \\
\hline & I challenge traditional ways of working when I think they can be improved. & 0.510 & & & \\
\hline \multirow{9}{*}{$\begin{array}{l}\text { 4: Building support } \\
\text { for change }\end{array}$} & I make my work visible in ways that help others. & 0.763 & \multirow[t]{9}{*}{0.875} & \multirow[t]{9}{*}{0.438} & \multirow[t]{9}{*}{32} \\
\hline & I collect, organise and share useful resources. & 0.729 & & & \\
\hline & I build support for change at work. & 0.604 & & & \\
\hline & I mobilise others to act on change. & 0.578 & & & \\
\hline & I inspire others to a shared purpose. & 0.560 & & & \\
\hline & I help others find solutions to challenges in leading change. & 0.549 & & & \\
\hline & I get people interested in change initiatives. & 0.511 & & & \\
\hline & I use storytelling to inspire change. & 0.487 & & & \\
\hline & I am very aware of my natural leadership style. & 0.384 & & & \\
\hline \multirow{4}{*}{$\begin{array}{l}\text { 5: Maintaining } \\
\text { relationships }\end{array}$} & I clash with colleagues about how we should work. & 0.735 & \multirow[t]{4}{*}{0.595} & \multirow[t]{4}{*}{0.269} & \multirow[t]{4}{*}{8} \\
\hline & I tend to be careless in how my behaviour or words affect others. & 0.660 & & & \\
\hline & I prefer to lead change by myself rather than collaborating with others. & 0.655 & & & \\
\hline & I am careful to frame what I want to say so that it has a positive impact. & 0.459 & & & \\
\hline
\end{tabular}

Rotation: Varimax with Kaiser Normalization; converged in 7 iterations.

${ }^{1}$ Single measures intraclass correlation coefficient.

${ }^{2}$ Cases excluded from sample $(\mathrm{N}=639)$ : listwise deletion. 
MOOCs and social learning: a healthcare sector case study

Table 3: Learner outcomes by factor, before-after comparison (paired samples t-test)

\begin{tabular}{|l|l|l|l|l|l|l|l|l|l|l|}
\hline & \multicolumn{3}{|c|}{ Paired Differences } & \multicolumn{3}{|c|}{} \\
\hline & $\mathrm{M}$ & $\mathrm{SD}$ & \multicolumn{2}{|c|}{$95 \%$ CI } & $\mathrm{d}$ & $\mathrm{t}$ & $\mathrm{df}$ & $\mathrm{N}$ & $\mathrm{p}$ \\
\hline $\begin{array}{l}\text { 1. Motivation for } \\
\text { change }\end{array}$ & 0.119 & 0.570 & 0.012 & 0.227 & 0.225 & 2.207 & 110 & 111 & 0.029 \\
$\begin{array}{l}\text { 2. Understanding of } \\
\text { change }\end{array}$ & 1.073 & 1.303 & 0.827 & 1.319 & 1.032 & 8.638 & 109 & 110 & 0.000 \\
\hline 3. Acting radically & 0.482 & 0.920 & 0.308 & 0.656 & 0.473 & 5.49 & 109 & 110 & 0.000 \\
\hline $\begin{array}{l}\text { 4. Building support } \\
\text { for change }\end{array}$ & 0.426 & 0.595 & 0.311 & 0.540 & 0.695 & 7.366 & 105 & 106 & 0.000 \\
\hline $\begin{array}{l}\text { 5. Maintaining } \\
\text { relationships }\end{array}$ & 0.102 & 0.745 & -0.039 & 0.243 & 0.139 & 1.439 & 109 & 110 & 0.153 \\
\hline
\end{tabular}


MOOCs and social learning: a healthcare sector case study

Table 4 - Interview data

\begin{tabular}{|c|c|c|c|}
\hline Focus & Theme & Frequency & Illustrative quotation \\
\hline $\begin{array}{l}\text { Learner outcome } \\
\text { (knowledge) }\end{array}$ & $\begin{array}{l}\text { Knowledge of } \\
\text { change methods }\end{array}$ & 10 & $\begin{array}{l}\text { As I went through each module, I found } \\
\text { I was learning new things about a larger } \\
\text { scale change and what it takes to move } \\
\text { from where we are currently which is } \\
\text { kind of day to day management of } \\
\text { change, and what it takes to kind of } \\
\text { move the dial a lot further on those } \\
\text { bigger scale changes that need to } \\
\text { happen (Interview 6). }\end{array}$ \\
\hline $\begin{array}{l}\text { Learner outcome: } \\
\text { (skills) }\end{array}$ & $\begin{array}{l}\text { Storytelling and } \\
\text { framing }\end{array}$ & 21 & $\begin{array}{l}\text { Instead of just berating people to } \\
\text { pledge, it would be things like telling } \\
\text { stories and trying to motivate internally } \\
\text { why people might want to make a } \\
\text { difference to the health and care system } \\
\text { that we work in (Interview 6) }\end{array}$ \\
\hline $\begin{array}{l}\text { Learner outcomes } \\
\text { (skills) }\end{array}$ & $\begin{array}{l}\text { Change } \\
\text { management skills }\end{array}$ & 4 & $\begin{array}{l}\text { And then all the skills and the effective } \\
\text { techniques, how you can achieve these } \\
\text { things. I think that was my main benefit } \\
\text { from School of Health and Care } \\
\text { Radicals (Interview 3). }\end{array}$ \\
\hline $\begin{array}{l}\text { Learner outcomes } \\
\text { (skills) }\end{array}$ & Self-awareness & 2 & $\begin{array}{l}\text { They were two of the things that stood } \\
\text { out for me because self-awareness is } \\
\text { something I try to work on. I find it } \\
\text { difficult but I do try to work on it } \\
\text { (Interview 12) }\end{array}$ \\
\hline $\begin{array}{l}\text { Learner outcome } \\
\text { (skills) }\end{array}$ & Inject new ideas & 1 & $\begin{array}{l}\text { I think that's partly what this, sort of, } \\
\text { year's school has done. Is to say that } \\
\text { there are lots of other ways of tackling } \\
\text { these things and all you have to do is, } \\
\text { sort of, go back and refresh. I think in } \\
\text { some ideas, you know, you pick them } \\
\text { up; you embed them immediately in } \\
\text { your thinking. But they are woven in so, } \\
\text { you can't, as you are speaking you don't } \\
\text { go, "Oh, hang on, that was from the } \\
\text { School of Radicals this year." } \\
\text { (Interview 11). }\end{array}$ \\
\hline $\begin{array}{l}\text { Learner outcome: } \\
\text { (attitudes) }\end{array}$ & $\begin{array}{l}\text { Empathy - other } \\
\text { perspectives }\end{array}$ & 21 & $\begin{array}{l}\text { I found the second course very helpful } \\
\text { in that helping to build- it helped me to } \\
\text { get empathy more with the individuals } \\
\text { and the way they were thinking within } \\
\text { the organisation (Interview 14). }\end{array}$ \\
\hline $\begin{array}{l}\text { Learner outcome } \\
\text { (attitudes) }\end{array}$ & $\begin{array}{l}\text { Confidence and } \\
\text { self-efficacy }\end{array}$ & 20 & $\begin{array}{l}\text { They now will seek out my opinion. I } \\
\text { will be able to put my hand up in a } \\
\text { meeting and they will actually give me a } \\
\text { chance to speak. So I do speak up in } \\
\text { meetings now which I wouldn't have }\end{array}$ \\
\hline
\end{tabular}


MOOCs and social learning: a healthcare sector case study

\begin{tabular}{|c|c|c|c|}
\hline & & & $\begin{array}{l}\text { done a year ago, absolutely not. Every } \\
\text { time I make sure I speak up in the } \\
\text { meeting. Now I'm there. They expect } \\
\text { me to be there. (Interview 13) }\end{array}$ \\
\hline $\begin{array}{l}\text { Learner outcome } \\
\text { (attitudes) }\end{array}$ & $\begin{array}{l}\text { Perseverance and } \\
\text { resilience }\end{array}$ & 15 & $\begin{array}{l}\text { Obviously there is a bit of resistance or } \\
\text { criticism is not easy to handle, but I } \\
\text { think I'm more proactive and maybe } \\
\text { more confident at least to share the } \\
\text { observations and ideas and see what } \\
\text { other people think. Some will work, } \\
\text { some won't (Interview 1). }\end{array}$ \\
\hline $\begin{array}{l}\text { Learner outcome } \\
\text { (attitudes) }\end{array}$ & $\begin{array}{l}\text { Realise the value of } \\
\text { relationships }\end{array}$ & 12 & $\begin{array}{l}\text { What I have realised is that I need to } \\
\text { raise my head up a little bit within the } \\
\text { organisation, make connections with } \\
\text { other people in other teams and use } \\
\text { them for support (Interview } 7 \text { ). }\end{array}$ \\
\hline $\begin{array}{l}\text { Learner outcome } \\
\text { (attitudes) }\end{array}$ & $\begin{array}{l}\text { Inspire and } \\
\text { motivate }\end{array}$ & 11 & $\begin{array}{l}\text { I think the approach that I would have } \\
\text { taken, prior to getting involved in the } \\
\text { school, would be to just sit at the head } \\
\text { of the table and explain what needs to } \\
\text { change. Whereas the difference that I } \\
\text { try to implement now is to try and get } \\
\text { people to be part of it, and understand } \\
\text { that it's the right thing to do. What that } \\
\text { means for them and have them come } \\
\text { with me, rather than me tell them } \\
\text { anything. I think that was what changed } \\
\text { (Interview 12). }\end{array}$ \\
\hline $\begin{array}{l}\text { Learner outcome } \\
\text { (attitudes) }\end{array}$ & $\begin{array}{l}\text { Assume permission } \\
\text { to act }\end{array}$ & 9 & $\begin{array}{l}\text { So what I did, I } \ldots \text { used the knowledge } \\
\text { from the School there that the leadership } \\
\text { come from the bottom and not the } \\
\text { top... So I got all the junior doctors } \\
\text { together and I have spoken to them and } \\
\text { I said, "It's our forum. Why don't we } \\
\text { take responsibility for this? (Interview } \\
\text { 3). }\end{array}$ \\
\hline $\begin{array}{l}\text { Learner outcome } \\
\text { (attitudes) }\end{array}$ & $\begin{array}{l}\text { Question the status } \\
\text { quo }\end{array}$ & 7 & $\begin{array}{l}\text { It was just a general team meeting and I } \\
\text { just brought up the fact that I thought } \\
\text { everyone was very unhappy and that we } \\
\text { needed to change the way we were } \\
\text { working. That then, as I say opened this } \\
\text { can of worms of how burnt out } \\
\text { everybody felt and how completely } \\
\text { bogged down with the amount of work } \\
\text { we were trying to do (Interview 7). }\end{array}$ \\
\hline $\begin{array}{l}\text { Learner outcomes } \\
\text { (attitudes) }\end{array}$ & $\begin{array}{l}\text { Maintain positive } \\
\text { relationships }\end{array}$ & 5 & $\begin{array}{l}\text { I might have, in the past, thought people } \\
\text { weren't doing something. I would have } \\
\text { maybe labelled them in my head as } \\
\text { laggards or resistors to change but now I } \\
\text { think of them, to try and understand }\end{array}$ \\
\hline
\end{tabular}


MOOCs and social learning: a healthcare sector case study

\begin{tabular}{|c|c|c|c|}
\hline & & & $\begin{array}{l}\text { their viewpoint and think maybe they } \\
\text { just don't know as much about what we } \\
\text { are doing. I've used that to try and } \\
\text { understand where they are coming from } \\
\text { so that we can move things forward } \\
\text { (Interview 9) }\end{array}$ \\
\hline $\begin{array}{l}\text { Learner outcome } \\
\text { (attitudes) }\end{array}$ & $\begin{array}{l}\text { Energy to deliver } \\
\text { on change }\end{array}$ & 5 & $\begin{array}{l}\text { Over the few weeks that I was doing the } \\
\text { module I think quite a lot, because I } \\
\text { became quite enthusiastic and positive } \\
\text { and saying, "Yes we can do this." And } \\
\text { trying to help the others see there was a } \\
\text { way forward (Interview 7). }\end{array}$ \\
\hline $\begin{array}{l}\text { Learner outcomes } \\
\text { (attitudes) }\end{array}$ & $\begin{array}{l}\text { Driven by personal } \\
\text { sense of purpose }\end{array}$ & 2 & $\begin{array}{l}\text { I'm not really sure, but I've definitely } \\
\text { got the confidence and motivation now } \\
\text { to try and move things forward. And, } \\
\text { personally, from a career develop point } \\
\text { of view, I want to change things for } \\
\text { myself, so I am more enthusiastic about } \\
\text { doing things (Interview 2). }\end{array}$ \\
\hline $\begin{array}{l}\text { Learner } \\
\text { experience }\end{array}$ & $\begin{array}{l}\text { Support and } \\
\text { validation through } \\
\text { network of peers }\end{array}$ & 25 & $\begin{array}{l}\text { Using the tools in the School for Health } \\
\text { and Care Radicals, it didn't feel like I'd } \\
\text { made the decision on my own, because I } \\
\text { used informal networks to send out an } \\
\text { idea, ask for views, check for sensitivity } \\
\text { (Interview 4) }\end{array}$ \\
\hline $\begin{array}{l}\text { Learner } \\
\text { experience }\end{array}$ & $\begin{array}{l}\text { Encourage and } \\
\text { support others }\end{array}$ & 18 & $\begin{array}{l}\text { Now, after being on the course, I think } \\
\text { I've got three wards that I work with so } \\
\text { I've got three different lots of people } \\
\text { that, because of the course, I try to get } \\
\text { to know them better rather than just } \\
\text { kind of go in and say, "You need to do } \\
\text { these things." It's more about } \\
\text { understanding where they are at. } \\
\text { (Interview 9). }\end{array}$ \\
\hline $\begin{array}{l}\text { Learner } \\
\text { experience }\end{array}$ & $\begin{array}{l}\text { Foster involvement } \\
\text { and support }\end{array}$ & 13 & $\begin{array}{l}\text { There are three other deputy sisters on } \\
\text { my ward, I tried to get them involved } \\
\text { with making sure they promoted it and } \\
\text { gave the stickers out. I particularly } \\
\text { homed in on people like the } \\
\text { receptionists, who sit at the main desk } \\
\text { and often hear people saying, "Oh, this } \\
\text { isn't going right," or, you know, } \\
\text { moaning (Interview 2). }\end{array}$ \\
\hline $\begin{array}{l}\text { Learner } \\
\text { experience }\end{array}$ & $\begin{array}{l}\text { Align with a shared } \\
\text { purpose and } \\
\text { mission }\end{array}$ & 12 & $\begin{array}{l}\text { There's also a comfort in knowing that } \\
\text { there other people out there who also } \\
\text { feel that, you know, that they want to } \\
\text { shake things up and do things }\end{array}$ \\
\hline
\end{tabular}


MOOCs and social learning: a healthcare sector case study

\begin{tabular}{|c|c|c|c|}
\hline & & & $\begin{array}{l}\text { differently and cut across the NHS } \\
\text { bureaucracy (Interview 11) }\end{array}$ \\
\hline $\begin{array}{l}\text { Learner } \\
\text { experience }\end{array}$ & Knowledge sharing & 11 & $\begin{array}{l}\text { It was good to hear from the tips of } \\
\text { what you all have experienced and what } \\
\text { other graduates have experienced and to } \\
\text { recommend and what we are doing } \\
\text { (Interview 10). }\end{array}$ \\
\hline $\begin{array}{l}\text { Learner } \\
\text { experience }\end{array}$ & $\begin{array}{l}\text { Reflect and distil } \\
\text { tacit knowledge }\end{array}$ & 1 & $\begin{array}{l}\text { There are a lot of years of experience in } \\
\text { the meeting. So we try and draw on that } \\
\text { and people get a chance to comment and } \\
\text { add to, and maybe discuss the } \\
\text { methodology and things like that } \\
\text { (Interview 13). }\end{array}$ \\
\hline $\begin{array}{l}\text { Workplace } \\
\text { context }\end{array}$ & $\begin{array}{l}\text { Sense of isolation / } \\
\text { experience of } \\
\text { organizational } \\
\text { inertia }\end{array}$ & 39 & $\begin{array}{l}\text { "I sometimes feel that I am a bit of a } \\
\text { lone voice when I talk about this kind of } \\
\text { thing, and when I talk about change and } \\
\text { transformation" (Interview 12) }\end{array}$ \\
\hline $\begin{array}{l}\text { Workplace } \\
\text { context }\end{array}$ & $\begin{array}{l}\text { Change oriented } \\
\text { work environment }\end{array}$ & 5 & $\begin{array}{l}\text { "Power through hierarchy, mission and } \\
\text { vision, they're all things that are very } \\
\text { familiar where I work". (Interview 12). }\end{array}$ \\
\hline $\begin{array}{l}\text { Workplace } \\
\text { context }\end{array}$ & $\begin{array}{l}\text { Management / } \\
\text { organizational } \\
\text { culture }\end{array}$ & 13 & $\begin{array}{l}\text { "It was very technical and compliant. I } \\
\text { think I've shifted over the last year to } \\
\text { much more of a commitment model } \\
\text { rather than a compliance model, so what } \\
\text { actually motivates people to change". } \\
\text { (Interview 6). }\end{array}$ \\
\hline $\begin{array}{l}\text { Personal / } \\
\text { professional } \\
\text { context }\end{array}$ & $\begin{array}{l}\text { Colleague / mentor } \\
\text { support }\end{array}$ & 15 & $\begin{array}{l}\text { "I heard about it through word of mouth } \\
\text { from somebody that I met at a } \\
\text { conference. She actually said that she } \\
\text { had enrolled on this course and I } \\
\text { thought, "This sounds just like me and I } \\
\text { would like to find out more about it". } \\
\text { So I enrolled on it myself, so it was } \\
\text { word of mouth" (Interview 5). }\end{array}$ \\
\hline $\begin{array}{l}\text { Personal / } \\
\text { Professional } \\
\text { context }\end{array}$ & $\begin{array}{l}\text { Personal / career } \\
\text { development }\end{array}$ & 6 & $\begin{array}{l}\text { "When I started on the course I was in a } \\
\text { different role and knew that I was } \\
\text { applying for quite a senior position, } \\
\text { which was for Head of Quality". } \\
\text { (Interview 5) }\end{array}$ \\
\hline $\begin{array}{l}\text { Personal / } \\
\text { Professional } \\
\text { context }\end{array}$ & $\begin{array}{l}\text { Previous quality } \\
\text { improvement/ } \\
\text { change agent } \\
\text { programme } \\
\text { involvement }\end{array}$ & 4 & $\begin{array}{l}\text { I came to Vancouver and did a one-day } \\
\text { school in February, which I attended. } \\
\text { There was such an emphasis on social } \\
\text { media and connections that I joined the } \\
\text { Twitter group, I joined the Facebook } \\
\text { group. I found a lot of support and a lot } \\
\text { of connections in that way. So I was } \\
\text { able to follow a lot more than I think I }\end{array}$ \\
\hline
\end{tabular}


MOOCs and social learning: a healthcare sector case study

\begin{tabular}{|c|c|c|c|}
\hline & & & $\begin{array}{l}\text { would have done otherwise". (Interview } \\
6 \text { ). }\end{array}$ \\
\hline $\begin{array}{l}\text { Social learning } \\
\text { technology }\end{array}$ & $\begin{array}{l}\text { Interaction with } \\
\text { others }\end{array}$ & 17 & $\begin{array}{l}\text { "I thought that the sharing via social } \\
\text { networking was important as well and } \\
\text { recognise the input from other } \\
\text { members". (Interview 14). }\end{array}$ \\
\hline $\begin{array}{l}\text { Social learning } \\
\text { technology }\end{array}$ & $\begin{array}{l}\text { Previous } \\
\text { experience }\end{array}$ & 6 & $\begin{array}{l}\text { "I liked the social media aspect of it and } \\
\text { I don't use all of that social media but I } \\
\text { know many people in the world do, so I } \\
\text { think it was interesting that you } \\
\text { embraced that and made that part of the } \\
\text { programme... It kind of brings } \\
\text { other people along in social media as } \\
\text { well, to use it, to participate but also } \\
\text { possibly to use it to make their change". } \\
\text { (Interview 10) }\end{array}$ \\
\hline $\begin{array}{l}\text { Social learning } \\
\text { technology }\end{array}$ & Accessibility & 4 & $\begin{array}{l}\text { "The thing that I struggled with was } \\
\text { we've actually got a restriction, where I } \\
\text { work, on Twitter and Facebook. The } \\
\text { sites are blocked by our information } \\
\text { governance team. So that was } \\
\text { something that I struggled with because } \\
\text { I haven't got a data plan on my mobile } \\
\text { phone, which I could have done as I } \\
\text { went. I'm not really familiar with } \\
\text { Twitter but I think it's given me a bit of } \\
\text { a nudge to get myself more familiar } \\
\text { with it, because I felt like I was missing } \\
\text { out a little bit on that". (Interview 12). }\end{array}$ \\
\hline $\begin{array}{l}\text { Social learning } \\
\text { technology }\end{array}$ & Social media skills & 3 & $\begin{array}{l}\text { "The Twitter thing, I had taken part in- } \\
\text { [colleague name] did a sort of training } \\
\text { on use of Twitter so because I was } \\
\text { doing that as the course was going on, it } \\
\text { enabled me to- I learnt how to use } \\
\text { Twitter and be part of it". (Interview 9). }\end{array}$ \\
\hline $\begin{array}{l}\text { Social learning } \\
\text { technology }\end{array}$ & $\begin{array}{l}\text { Learning } \\
\text { fragmentation }\end{array}$ & 2 & $\begin{array}{l}\text { "I found listening to the actual } \\
\text { presentation .....and with the Chatbox } \\
\text { going on as well and the slides, it was } \\
\text { plenty for me to be trying to take in at } \\
\text { one time, without even thinking about } \\
\text { Twitter or Facebook as well. ... I know } \\
\text { that a lot of people got a lot out of } \\
\text { Twitter but I'm not really a social }\end{array}$ \\
\hline
\end{tabular}


MOOCs and social learning: a healthcare sector case study

\begin{tabular}{|l|l|l|l|}
\hline & & $\begin{array}{l}\text { networker anyway... but there was a lot } \\
\text { going on, on screen believe me". } \\
\text { (Interview 13). }\end{array}$ \\
\hline $\begin{array}{l}\text { Social learning } \\
\text { technology }\end{array}$ & $\begin{array}{l}\text { Personal- } \\
\text { professional } \\
\text { boundaries }\end{array}$ & 2 & $\begin{array}{l}\text { "Yes, like I said I found that the tweet } \\
\text { chats were really beneficial. But the } \\
\text { Facebook page I didn't use that, } \\
\text { because my account on Facebook is } \\
\text { personal not professional, so I just } \\
\text { wouldn't have used that". (Interview 5). }\end{array}$ \\
\hline
\end{tabular}


MOOCs and social learning: a healthcare sector case study

Table 5: Engagement with online and face-to-face social learning and learner outcomes (t-test for equality of means)

\begin{tabular}{|c|c|c|c|c|c|c|c|c|}
\hline $\begin{array}{l}\text { Any online social learning } \\
\text { (1=yes): }\end{array}$ & $\mathrm{t}$ & $\mathrm{N}$ & df & $\mathrm{p}$ & MD & $\mathrm{SE}$ & $95 \% \mathrm{CI}$ & \\
\hline 1. Motivation for change & -1.024 & 111 & 109 & 0.308 & -0.131 & 0.128 & -0.384 & 0.122 \\
\hline 2. Understanding of change & 0.019 & 110 & 108 & 0.985 & 0.005 & 0.294 & -0.577 & 0.588 \\
\hline 3. Acting radically & -0.093 & 110 & 108 & 0.926 & -0.020 & 0.210 & -0.437 & 0.397 \\
\hline 4. Building support for change & -1.081 & 106 & 104 & 0.282 & -0.149 & 0.138 & -0.423 & 0.124 \\
\hline 5. Maintaining relationships & -0.875 & 110 & 108 & 0.383 & -0.147 & 0.167 & -0.478 & 0.185 \\
\hline \multicolumn{9}{|l|}{$\begin{array}{l}\text { Participated in a team } \\
(0=\text { alone; } 1=\text { team }):\end{array}$} \\
\hline 1. Motivation for change & -0.205 & 110 & 108 & 0.838 & -0.031 & 0.153 & -0.334 & 0.272 \\
\hline $\begin{array}{l}\text { 2. Understanding of change } \\
\text { models }\end{array}$ & 0.938 & 109 & 107 & 0.350 & 0.332 & 0.354 & -0.369 & 1.032 \\
\hline 3. Acting radically & 1.093 & 109 & 107 & 0.277 & 0.273 & 0.250 & -0.222 & 0.769 \\
\hline 4. Building support for change & 0.859 & 105 & 103 & 0.392 & 0.137 & 0.160 & -0.180 & 0.454 \\
\hline 5. Maintaining relationships & -3.013 & 109 & 107 & 0.003 & -0.580 & 0.192 & -0.961 & -0.198 \\
\hline
\end{tabular}

Equal variances assumed.

Table 6: Impact of participating in a team on the increase in 'maintaining relationships' capability: mean difference and effect size

\begin{tabular}{|l|c|c|c|c|c|c|c|}
\hline & $\begin{array}{c}\text { Mean } \\
\text { increas } \\
\mathrm{e}\end{array}$ & SD & SEM & $\mathrm{N}$ & $\mathrm{d}$ & \multicolumn{2}{|c|}{$95 \% \mathrm{CI}$} \\
\hline Participated alone & 0.0296 & $\begin{array}{c}0.7174 \\
5\end{array}$ & $\begin{array}{c}0.0744 \\
0\end{array}$ & 93 & 0.815 & 0.27 & $\begin{array}{c}1.356 \\
8\end{array}$ \\
\hline $\begin{array}{l}\text { Participated in a } \\
\text { team }\end{array}$ & 0.6094 & $\begin{array}{c}0.6706 \\
3\end{array}$ & $\begin{array}{c}0.1676 \\
6\end{array}$ & 16 & 4 & 4 & 8 \\
\hline
\end{tabular}

\section{Appendix}

Table A1: Respondent age and engagement with online and face-to-face social learning (comparison of means)

\begin{tabular}{|c|c|c|c|c|c|c|c|c|c|}
\hline \multirow{3}{*}{$\begin{array}{l}\text { Online chats during } \\
\text { modules }\end{array}$} & & $\mathrm{N}$ & $\mathrm{M}$ & $\mathrm{t}$ & df & $\mathrm{p}$ & SEM & $95 \% \mathrm{Cl}$ & \\
\hline & No & 37 & 44.89 & \multirow{2}{*}{0.89} & \multirow{2}{*}{83} & \multirow{2}{*}{0.376} & \multirow{2}{*}{2.15} & \multirow{2}{*}{-2.364} & \multirow{2}{*}{6.19} \\
\hline & Yes & 48 & 42.98 & & & & & & \\
\hline \multirow{2}{*}{$\begin{array}{l}\text { Connected with others } \\
\text { via social media }\end{array}$} & No & 39 & 45.13 & \multirow{2}{*}{1.14} & \multirow{2}{*}{83} & \multirow{2}{*}{0.257} & \multirow{2}{*}{2.133} & \multirow{2}{*}{-1.81} & \multirow{2}{*}{6.675} \\
\hline & Yes & 46 & 42.7 & & & & & & \\
\hline \multirow{2}{*}{$\begin{array}{l}\text { Participated alone or } \\
\text { with a team }\end{array}$} & Alone & 72 & 43.64 & \multirow{2}{*}{-0.38} & \multirow{2}{*}{83} & \multirow{2}{*}{0.705} & \multirow{2}{*}{2.973} & \multirow{2}{*}{-7.044} & \multirow{2}{*}{4.784} \\
\hline & Team & 13 & 44.77 & & & & & & \\
\hline
\end{tabular}

Equal variances assumed 
MOOCs and social learning: a healthcare sector case study

Table A2: Respondent gender and engagement with online and face-to-face social learning (Chisquared test)

\begin{tabular}{|l|r|r|r|r|r|r|}
\hline & $\begin{array}{l}\text { Female } \\
(\mathrm{N}=62)\end{array}$ & $\begin{array}{l}\text { Male } \\
(\mathrm{N}=22)\end{array}$ & $\begin{array}{l}\text { Prefer not } \\
\text { to say } \\
(\mathrm{N}=2)\end{array}$ & \multicolumn{1}{|l|}{$\chi^{2}$} & $\mathrm{df}$ & $\mathrm{p}$ \\
\hline $\begin{array}{l}\text { Online chats during } \\
\text { modules (\%) }\end{array}$ & 56.5 & 59.1 & 0.0 & 2.632 & 2 & 0.268 \\
\hline $\begin{array}{l}\text { Connected with others } \\
\text { via social media (\%) }\end{array}$ & 51.6 & 59.1 & 0.0 & 2.611 & 2 & 0.271 \\
\hline $\begin{array}{l}\text { Participated with a } \\
\text { team, not alone (\%) }\end{array}$ & 11.3 & 27.3 & 0.0 & 3.384 & 2 & 0.184 \\
\hline
\end{tabular}

Table A3: Seniority in organisation and engagement with online and face-to-face social learning (correlations)

\begin{tabular}{|l|r|r|r|}
\hline & $\rho($ rho $)$ & N & \multicolumn{1}{l|}{ p } \\
\hline Online chats during modules (1=yes) & 0.111 & 74 & 0.347 \\
\hline Connected with others via social media (1=yes) & -0.134 & 74 & 0.255 \\
Participated in a team (0=alone, 1=team) & 0.018 & 74 & 0.877 \\
\hline
\end{tabular}

Seniority: six category variable of number of levels between respondent and the CEO $(1=$ "I am the CEO"; 6="Five or more levels below the CEO"). 